\title{
Efek Radiasi Sinar Matahari dan Sinar Ultra Violet pada Plastik Styrofoam Kemasan Makanan dan Minuman
}

\author{
Sumari*, Nazriati, Fauziatul Fajaroh, Aman Santosa \& Lailatur Rizqiyah \\ Jurusan Kimia, Fakultas Matematika dan Ilmu Pengetahuan Alam, Universitas Negeri Malang, Indonesia \\ Corresponding author: sumari.fmipa@um.ac.id
}

\section{Article history}

Received: 30 Agustus 2019

Received in revised form:

21 November 2019

Accepted: 26 November 2019

DOI:

10.17977/um0260v3i12019p023

Kata-kata kunci:

Degradasi,

Plastik kemasan

Sinar UV

Styrofoam

\begin{abstract}
Abstrak
Penelitian bertujuan untuk mengetahui efek radiasi sinar matahari dan sinar ultra violet pada plastik styrofoam kemasan makanan dan minuman. Sampel yang digunakan pada penelitian ini adalah styrofoam pengemas makanan dan minuman. Lembaran styrofoam dibuat film tipis dan lempeng tipis, selanjutnya sebagian sampel dipaparkan pada sinar matahari dan sebagian sampel dipaparkan sinar ultra violet menggunakan lampu uv dengan daya 20 watt dalam waktu yang sama yaitu 10, 25, dan 40 hari. Karakterisasi styrofoam meliputi uji tarik, spektroskopi infra merah, dan pengamatan fisik. Hasil penelitian ini menunjukkan bahwa radiasi sinar matahari maupun sinar ultra violet dapat menyebabkan degradasi pada styrofoam. Radiasi sinar matahari dan sinar ultra violet pada styrofoam dapat menyebabkan penurunan kekuatan tarik, peningkatan konsentrasi relatif stirena oksida, perubahan warna sampel dari putih menjadi kuning dan timbul retakan. Semakin lama waktu radiasi baik radiasi sinar matahari maupun sinar ultra violet dapat mempercepat degradasi.
\end{abstract}

\begin{abstract}
The widespread use of styrofoam as food and beverage packaging is a very urgent issue to study, especially regarding to human health. This polymer is thought to be easily degraded by beam radiation to produce monomers that are easily oxidized to carcinogenic styrene oxides. Studies on the effects of sun and UV rays on plastic for food and beverage packaging have been carried out. Some styrofoam samples are made in the form of thin films and some are made in slabs. The samples were exposed to sunlight and the others were exposed to ultraviolet light using 20 watts UV lamps for 10, 25, and 40 days. The effects of radiation on styrofoam were characterized using a tensile test, FTIR, and physical observation. The results showed that both sun and ultraviolet radiation can cause degradation of styrofoam. Radiation of sunlight and UV light on styrofoam generate a decrease in tensile strength, an increase in the relative concentration of styrene oxide, a change in the color of the sample from white to yellow, and cracks arise. The longer the time of sun and ultraviolet radiation can accelerate styrofoam plastics degradation.
\end{abstract}

\section{PENDAHULUAN}

Plastik merupakan salah satu bahan yang paling umum kita lihat dan gunakan. Bahan plastik secara bertahap mulai menggantikan gelas, kayu, dan logam. Hal ini disebabkan plastik mempunyai beberapa keunggulan, antara lain ringan, kuat dan mudah dibentuk, anti karat dan tahan terhadap bahan kimia, mempunyai sifat isolasi listrik yang tinggi, dapat dibuat berwarna maupun transparan, dan biaya proses yang lebih murah (Shrivastava, 2018). Saat ini plastik sering digunakan sebagai pengemas makanan dan minuman salah satunya adalah polystyrene foam atau styrofoam. Harganya murah, ringan, dan kelihatan eksklusif sehingga orang-orang tertarik menggunakannya (Demirkir et al., 2013). Namun, styrofoam yang kontak langsung dengan makanan dan minuman sebenarnya berbahaya, karena dimungkinkan terjadi migrasi zat-zat yang 
terkandung dalam styrofoam ke dalam makanan dan minuman (Chen et al., 2019).

Dalam kehidupan sehari-hari banyak penjual makanan atau minuman yang menggunakan styrofoam sebagai kemasan. Kemasan makanan ataupun minuman ini disimpan dalam almari kaca atau etalase yang terkena sinar matahari secara langsung. Polimer bila terkena panas ataupun sinar matahari akan terurai atau terdegradasi. Styrofoam, merupakan polimer yang bila terdegradasi membentuk monomer-monomernya yaitu stirena. Senyawa tersebut dapat bereaksi cepat dengan oksigen membentuk stirena oksida. Hal ini dapat membahayakan kesehatan karena ketika stirena oksida migrasi ke dalam tubuh dapat menyebabkan mutasi gen dan merangsang sel kanker (Cavallo et al., 2018).

Di negara-negara maju seperti Jepang dan negara Eropa penggunaan styrofoam sudah dilarang, sedangkan di Cina masih menjadi polemik. Tidak diperbolehkannya penggunaan styrofoam selain alasan yang berhubungan dengan kesehatan, juga berhubungan dengan pemusnahannya yang sangat sulit. Di Indonesia pengemas ini justru digemari oleh kalangan masyarakat karena harganya yang ekonomis. Pemakaian styrofoam sebagai wadah makanan menimbulkan kekhawatiran dan protes dari berbagai pihak. Berdasarkan berbagai penelitian yang dilakukan diketahui bahwa stirena, bahan dasar styrofoam, bersifat mutagenik (mampu mengubah gen) dan potensial karsinogen (merangsang sel kanker) (Huff and Infante, 2011), (FLEIG and THIESS, 1978). Demikian pula butadien sebagai bahan penguat maupun DOP atau BHT sebagai plasticizer -nya. Pada Juli 2001, Divisi Keamanan Pangan Pemerintah Jepang mengungkapkan bahwa residu styrofoam dalam makanan sangat berbahaya. Residu itu dapat menyebabkan endocrine disrupter (EDC), yaitu suatu penyakit yang terjadi akibat adanya gangguan pada sistem endokrinologi dan reproduksi manusia akibat bahan kimia karsinogen dalam makanan. Selain itu styrofoam dapat mengganggu sistem reproduksi yang mengakibatkan kemandulan atau menurunkan fertilitas. Anak yang biasa bermain-main dengan mainan yang terbuat dari polistirena dan sering menggigit mainan tersebut, dapat kehilangan kreativitas dan menjadi pasif (Editors, 2014).

Penelitian yang dilakukan beberapa peneliti menunjukkan bahwa radiasi sinar matahari dan sinar ultra violet terhadap polistirena dapat menyebabkan terjadinya degradasi polistirena membentuk monomer stirena yang kemudian teroksidasi menjadi stirena oksida (de Bomfim et al., 2019). Penelitian lain menunjukkan bahwa semakin lama waktu radiasi sinar ultra violet terhadap poliblend HDPE-pati dapat menurunkan nilai kekuatan tarik dan viskositasnya karena poliblend tersebut terdegradasi (Martínez-Romo et al., 2015). Penggunaan material plastik terutama banyak digunakan di bagian luar ruangan yang terkena sinar matahari. Demikian juga seringkali dalam etalase digunakan lampu sinar ultra violet untuk sterilisasi ruangan. Oleh karena itu perlu dipelajari ketahanan plastik styrofoam yang biasa digunakan pengemas makanan terhadap paparan radiasi sinar matahari dan sinar ultra violet.

\section{METODE}

\section{Alat dan Bahan}

Alat yang digunakan untuk preparasi dan treatment penelitian adalah cawan petri, dua buah lampu ultra violet dengan daya listrik 20 watt, kotak lampu ultra violet berukuran lebar $0,5 \mathrm{~m}$; tinggi $0,5 \mathrm{~m}$; dan panjang $0,75 \mathrm{~m}$; magnetic stirer, mikrometer sekrup, beaker glass, neraca analitik merk AND HF-300, cetakan kaca. Alat untuk karakterisasi adalah Universal Testing Machine (uji tarik) dan FTIR-8400S merk Shimadzu (analaisis gugus fungsi). Bahan yang digunakan adalah lembaran styrofoam kemasan makanan dan minuman dan pelarut toluena.

\section{Prosedur}

Pembuatan film dari styrofoam untuk analisis infra merah

Styrofoam lembaran dibersihkan, kemudian dipotong kecil-kecil dan ditimbang sebanyak 0,3 gram. Setelah itu sampel dilarutkan dengan toluena, diaduk menggunakan magnetic stirer sampai larut kemudian dituangkan dalam cawan petri dan dibiarkan sampai kering. Film tipis dibuat sebanyak tujuh buah dengan ketebalan film sekitar $0,1 \mathrm{~mm}$.

\section{Pembuatan lempeng dari styrofoam untuk} analisis kekuatan tarik

Cara pembuatannya sama seperti film tipis, hanya berbeda berat sampel yang digunakan. Styrofoam sebanyak 6 gram dilarutkan dengan toluena dan diaduk menggunakan magnetic stirer. Larutan styrofoam dituang dalam cetakan dan dibiarkan sampai kering.

\section{Perlakuan Sampel dengan Radiasi Sinar Matahari}

Sampel berupa film tipis dan lempeng tipis masing-masing diletakkan dalam enam buah cawan petri. Setelah itu film tipis dikenai 
penyinaran dengan sinar matahari. Radiasi sampel dengan sinar matahari dengan variasi lama penyinaran 10, 25, dan 40 hari.

\section{Perlakuan Sampel dengan Radiasi Sinar Ultra Violet}

Menyiapkan lampu ultra violet dengan kekuatan 20 watt sebanyak dua buah, kemudian menyiapkan kotak yang berbentuk kubus dengan semua sisi tertutup dan bagian dalamnya dilapisi dengan aluminium foil. Film tipis dan lempeng tipis yang sudah disiapkan masing-masing diletakkan dalam enam cawan petri, kemudian dimasukkan dalam kotak penyinaran sinar ultra violet yang telah dibuat. Radiasi dengan sinar ultra violet dilakukan terhadap sampel uji dengan variasi lama penyinaran 10, 25, dan 40 hari.

\section{Karakterisasi}

\section{Kekuatan Tarik}

Lempeng tipis yang berbentuk lembaran diukur ketebalannya menggunakan digital micrometer. Bagian sampel yang mempunyai ketebalan sama dibentuk dumbell dengan menggunakan alat pencetak dumbell berdimensi ISO 527 type 5A seperti pada Gambar 1. Kekuatan tarik dumbell sampel diukur dengan alat Universal Testing Machine.

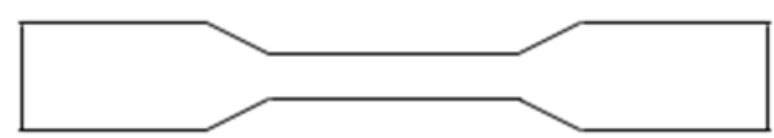

Gambar 1. Dumbell

\section{Analisis gugus fungsi dengan FTIR}

Film tipis yang telah dikenai radiasi sinar matahari dan sinar ultra violet kemudian dianalisis gugus fungsi yang ada dengan alat FTIR. Untuk mengetahui pengaruh lama penyinaran atau radiasi terhadap degradasi dapat dilakukan pengukuran absorbansi puncak ikatan C-O. Untuk mengukur besarnya absorbansi dari spektrum infra merah. Pengukuran absorbansi puncak ikatan C-O dilakukan dengan metode "base-line" (Sastrohamidjojo, 1990: 114) seperti terlihat pada Gambar 2.

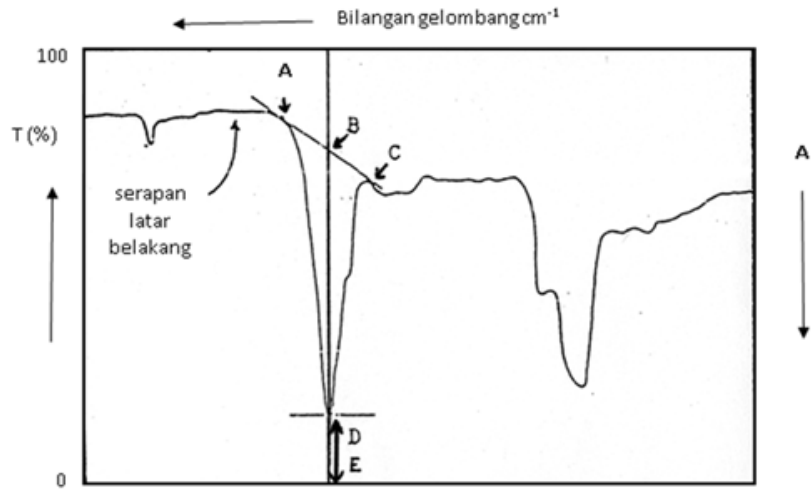

Gambar 2. Cara Mengukur Absorbansi dari Sampel Perlakuan

$$
\mathrm{A}=\log \mathrm{BE} / \mathrm{DE}
$$

dengan $\mathrm{Io}=\mathrm{BE}$ dan $\mathrm{I}=\mathrm{DE}$, sedangkan pengukuran ketebalan sampel digunakan alat mikrometer sekrup. (Sastrohamidjojo, 1990: 114)

\section{Pengamatan Fisik pada Lempeng Tipis}

Lempeng tipis yang telah dikenai radiasi sinar matahari dan sinar ultra violet dilakukan pengamatan fisik yang meliputi penampakan permukaan dan warna secara visual. Pengamatan ini dilakukan setelah selesai dilakukan radiasi selama waktu yang telah ditentukan.

\section{HASIL DAN PEMBAHASAN}

\section{Kekuatan Tarik}

Hasil pengujian kekuatan tarik dengan menggunakan alat Universal Testing Machine diperoleh data pada berbagai perlakuan radiasi ditunjukkan pada Tabel 1. Hubungan antara kekuatan tarik dengan lama waktu radiasi yang ditunjukkan pada Gambar 1.

Tabel 1. Data Kekuatan Tarik dari Berbagai Perlakuan

\begin{tabular}{lcc}
\multicolumn{3}{c}{ Radiasi } \\
$\begin{array}{l}\text { Jenis } \\
\text { Radiasi }\end{array}$ & $\begin{array}{l}\text { Lama } \\
\text { Radiasi } \\
\text { (hari) }\end{array}$ & $\begin{array}{l}\text { Kekuatan Tarik } \\
\text { (MPa) }\end{array}$ \\
\hline \multicolumn{1}{c}{ Sinar } & 0 (kontrol) & 23,6 \\
Matahari & 10 & 22,0 \\
& 25 & 20,6 \\
& 40 & 16,7 \\
\hline Sinar Ultra & 0 (kontrol) & 23,6 \\
Violet & 10 & 21,7 \\
& 25 & 20,5 \\
& 40 & 16,2 \\
\hline
\end{tabular}




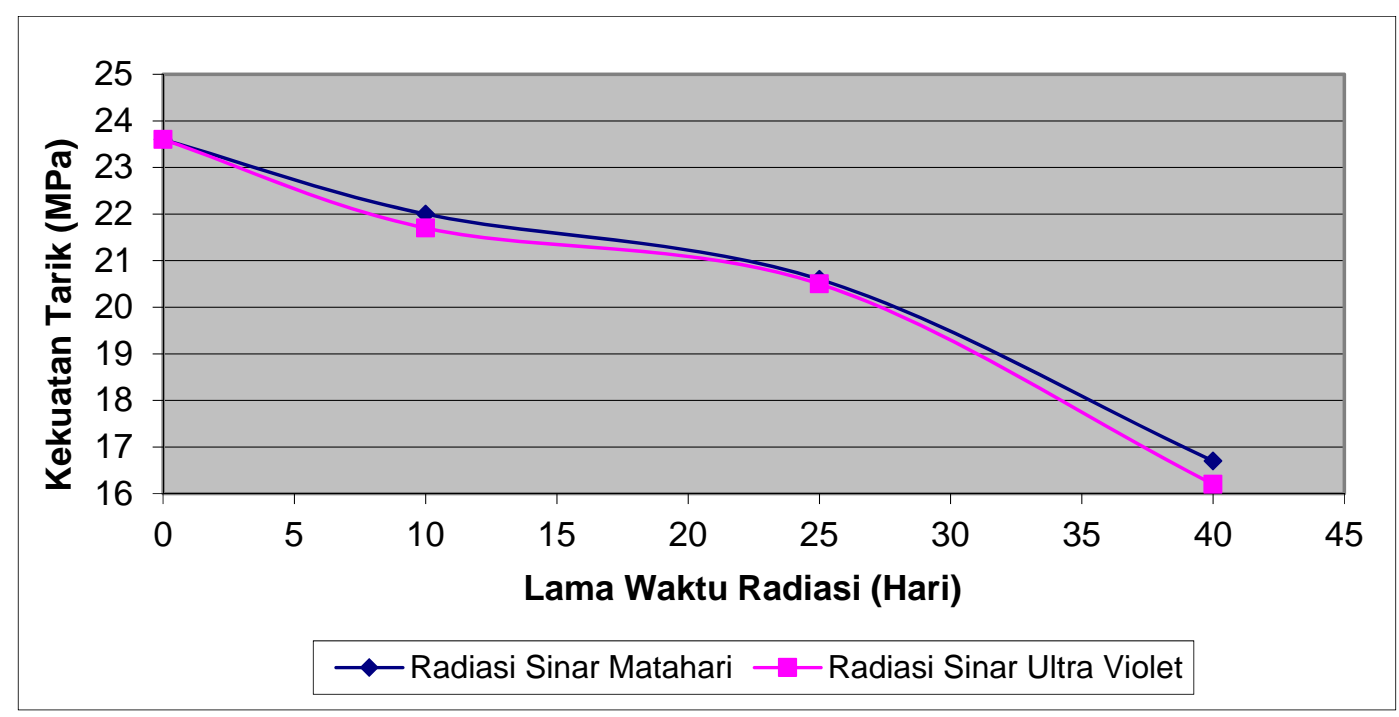

Gambar 3. Grafik Kekuatan Tarik dari Berbagai Perlakuan Radiasi

Berdasarkan Gambar 3 dapat dilihat bahwa pada semua sampel tersebut menunjukkan terjadinya penurunan kekuatan tarik akibat radiasi sinar matahari maupun sinar ultra violet. Hal ini dapat dikatakan bahwa baik radiasi sinar matahari dan sinar UV dapat menyebabkan degradasi styrofoam. Akibatnya kekuatan tarik sampel menurun. Penelitian yang telah dilakukan oleh Mobrianto (2003) menyatakan bahwa lama radiasi sinar ultra violet terhadap poliblend HDPE-Pati semakin menurunkan kekuatan tarik dan viskositasnya. Penelitian tersebut selaras dengan penelitian ini, bahwa radiasi sinar matahari maupun sinar ultra violet dapat menurunkan kekuatan tarik dari styrofoam. Makin lama perlakuan radiasi, baik radiasi sinar matahari maupun sinar ultra violet, makin besar terjadinya degradasi yang terjadi pada styrofoam yang menyebabkan penurunan kekuatan tarik pada sampel.

\section{Analisis Gugus Fungsi}

Langkah awal yang dilakukan adalah membandingkan spektra IR sampel dengan spektra standar polistirena murni. Berdasarkan hasil matching komputer, kemiripan styrofoam yang dijadikan sampel sebesar 89,5\%. Data ini menunjukkan bahwa komponen utama styrofoam adalah polistirena. Kemudian hasil spektrum
FTIR kontrol dan sampel dengan perlakuan radiasi sinar matahari maupun sinar ultra violet disajikan pada Gambar 4. Dengan menggunakan Tabel spektra infra merah standar berbagai gugus fungsi, dapat diidentifikasi gugus-gugus fungsi dari masing-masing puncak spektrum sampel. Hasil analisis puncak-puncak spektrum disajikan pada Tabel 2 sampai dengan Tabel 8.

Tabel 2 Hasil Analisis Gugus Fungsi Spektrum Infra Merah dari Sampel Kontrol

\begin{tabular}{|c|c|}
\hline $\begin{array}{l}\text { Bilangan } \\
\text { Gelombang }\left(\mathrm{cm}^{-1}\right)\end{array}$ & $\begin{array}{l}\text { Gugus Fungsi yang } \\
\text { Menyebabkan Absorbsi }\end{array}$ \\
\hline $3081,07-3026,01$ & Ulur C-H aromatik \\
\hline 2923,88-2849,63 & Ulur C-H alkana \\
\hline $1943,15-1747,39$ & Tekuk C-H aromatik \\
\hline $1681,81-1650,95$ & $\begin{array}{l}\text { Ulur } \mathrm{C}=\mathrm{C} \text { alkena dalam } \\
\text { stirena }\end{array}$ \\
\hline $1600,81-1492,80$ & Ulur $\mathrm{C}=\mathrm{C}$ aromatik \\
\hline 1450,37 & Ulur C-H dalam stirena \\
\hline $1371,29-1027,02$ & $\begin{array}{l}\text { Tekuk luar bidang } \mathrm{C}-\mathrm{H} \\
\text { aromatik }\end{array}$ \\
\hline $964,34-907,45$ & $\begin{array}{l}\text { Tekuk luar bidang C-H dalam } \\
\text { stirena }\end{array}$ \\
\hline 841,87 dan 755,08 & Ulur C-O epoksida \\
\hline $702,04-541,00$ & $\begin{array}{l}\text { Tekuk luar bidang C-H } \\
\text { aromatik }\end{array}$ \\
\hline
\end{tabular}



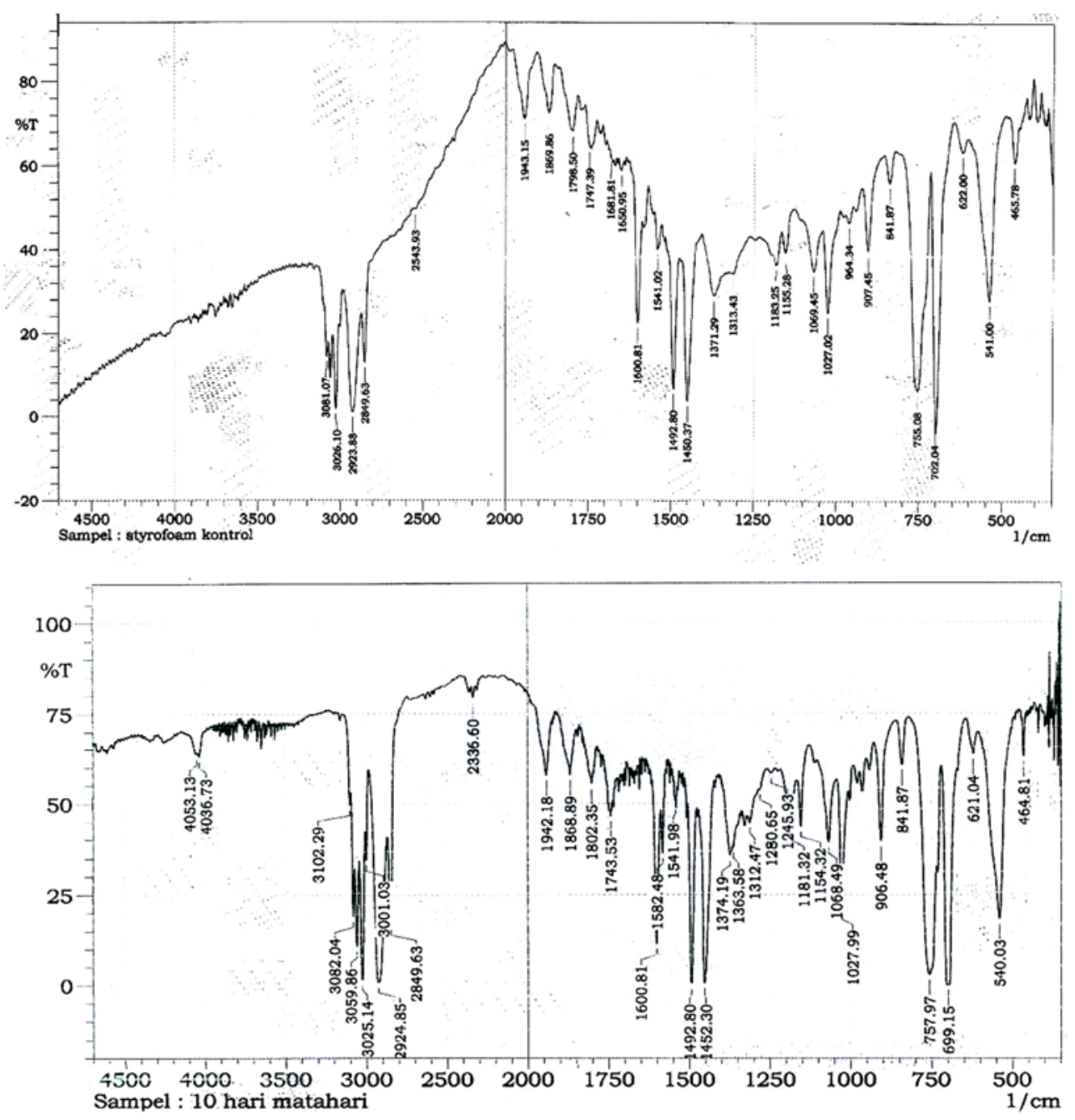

Gambar 4. Spektra IR Sampel Kontrol (0 hari) dan Salah Satu Sampel Setelah Diradiasi dengan Sinar Matahari Selama 10 Hari

Tabel 3. Hasil Analisis Gugus Fungsi Spektrum Infra Merah Sampel Perlakuan Radiasi Sinar Matahari Selama 10 Hari

\begin{tabular}{ll}
\hline $\begin{array}{l}\text { Bilangan } \\
\text { Gelombang }\left(\mathbf{c m}^{-\mathbf{1}}\right)\end{array}$ & $\begin{array}{l}\text { Gugus Fungsi yang } \\
\text { Menyebabkan Absorbsi }\end{array}$ \\
\hline 3102,29-3025,14 & Ulur C-H aromatik \\
2924,85-2849,63 & Ulur C-H alkana \\
1942,18-1743,53 & Tekuk C-H aromatik \\
1681,81-1650,95 & Ulur C=C alkena dalam stirena \\
1600,81-1492,80 & Ulur C=C aromatik \\
1452,30 & Ulur C-H dalam stirena \\
1374,19-1027,99 & Tekuk luar bidang C-H \\
& aromatik \\
964,34-906,48 & $\begin{array}{l}\text { Tekuk luar bidang C-H dalam } \\
\text { stirena } \\
\text { 841,87 dan 757,97 }\end{array}$ \\
Ulur C-O epoksida Tekuk luar \\
bidang C-H aromatik
\end{tabular}

Tabel 4. Hasil Analisis Gugus Fungsi Spektrum Infra Merah Sampel Perlakuan Radiasi Sinar Matahari Selama 25 Hari

\begin{tabular}{|c|c|}
\hline $\begin{array}{l}\text { Bilangan } \\
\text { Gelombang }\left(\mathrm{cm}^{-1}\right)\end{array}$ & $\begin{array}{l}\text { Gugus Fungsi yang } \\
\text { Menyebabkan Absorbsi }\end{array}$ \\
\hline $3082,04-3025,14$ & Ulur C-H aromatik \\
\hline 2923,88-2849,63 & Ulur C-H alkana \\
\hline $1943,15-1743,53$ & Tekuk C-H aromatik \\
\hline $1681,81-1650,95$ & Ulur $\mathrm{C}=\mathrm{C}$ alkena dalam stirena \\
\hline $1600,81-1492,80$ & Ulur $\mathrm{C}=\mathrm{C}$ aromatik \\
\hline 1452,30 & Ulur C-H dalam stirena \\
\hline $1373,22-1027,99$ & $\begin{array}{l}\text { Tekuk luar bidang } \mathrm{C}-\mathrm{H} \\
\text { aromatik }\end{array}$ \\
\hline $964,34-906,48$ & $\begin{array}{l}\text { Tekuk C-H luar bidang dalam } \\
\text { stirena }\end{array}$ \\
\hline 841,87 dan 757,01 & Ulur C-O epoksida \\
\hline $699,15-540,03$ & $\begin{array}{l}\text { Tekuk luar bidang } \mathrm{C}-\mathrm{H} \\
\text { aromatik }\end{array}$ \\
\hline
\end{tabular}


Tabel 5. Hasil Analisis Gugus Fungsi Spektrum Infra Merah Sampel Perlakuan Radiasi Sinar Matahari Selama 40 Hari

\begin{tabular}{|c|c|}
\hline $\begin{array}{l}\text { Bilangan } \\
\text { Gelombang }\left(\mathrm{cm}^{-1}\right) \\
\end{array}$ & $\begin{array}{l}\text { Gugus Fungsi yang } \\
\text { Menyebabkan Absorbsi }\end{array}$ \\
\hline $3102,29-3001,03$ & Ulur C-H aromatik \\
\hline $2920,99-2849,63$ & Ulur C-H alkana \\
\hline $1942,18-1743,53$ & Tekuk C-H aromatik \\
\hline 1668,31 & Ulur $\mathrm{C}=\mathrm{C}$ alkena dalam stirena \\
\hline $1600,81-1492,80$ & Ulur $\mathrm{C}=\mathrm{C}$ aromatik \\
\hline 1452,30 & Ulur C-H dalam stirena \\
\hline $1373,22-1027,99$ & $\begin{array}{l}\text { Tekuk luar bidang } \mathrm{C}-\mathrm{H} \\
\text { aromatik }\end{array}$ \\
\hline $964,34-906,48$ & $\begin{array}{l}\text { Tekuk luar bidang C-H dalam } \\
\text { stirena }\end{array}$ \\
\hline 841,87 dan 757,01 & Ulur C-O epoksida \\
\hline $694,33-540,03$ & $\begin{array}{l}\text { Tekuk luar bidang C-H } \\
\text { aromatik }\end{array}$ \\
\hline
\end{tabular}

Tabel 6. Hasil Analisis Gugus Fungsi Spektrum Infra Merah Sampel Perlakuan Radiasi Sinar UV Selama 10 Hari

\begin{tabular}{|c|c|}
\hline $\begin{array}{l}\text { Bilangan } \\
\text { Gelombang }\left(\mathrm{cm}^{-1}\right)\end{array}$ & $\begin{array}{l}\text { Gugus Fungsi yang } \\
\text { Menyebabkan Absorbsi }\end{array}$ \\
\hline $3101,32-3002,00$ & Ulur C-H aromatik \\
\hline 2928,71-2849,63 & Ulur C-H alkana \\
\hline $1943,15-1747,39$ & Tekuk C-H aromatik \\
\hline 1669,28 & $\begin{array}{l}\text { Ulur } \mathrm{C}=\mathrm{C} \text { alkena dalam } \\
\text { stirena }\end{array}$ \\
\hline $1600,81-1492,80$ & Ulur $\mathrm{C}=\mathrm{C}$ aromatik \\
\hline 1450,37 & Ulur C-H dalam stirena \\
\hline 1373,22-1027,99 & $\begin{array}{l}\text { Tekuk luar bidang } \mathrm{C}-\mathrm{H} \\
\text { aromatik }\end{array}$ \\
\hline $964,34-906,48$ & $\begin{array}{l}\text { Tekuk luar bidang } \mathrm{C}-\mathrm{H} \\
\text { dalam stirena }\end{array}$ \\
\hline 841,87 dan 758,94 & Ulur C-O epoksida \\
\hline $750,26-540,03$ & $\begin{array}{l}\text { Tekuk luar bidang } \mathrm{C}-\mathrm{H} \\
\text { aromatik }\end{array}$ \\
\hline
\end{tabular}

Tabel 7. Hasil Analisis Gugus Fungsi Spektrum Infra Merah Sampel Perlakuan Radiasi Sinar UV Selama 25 Hari

\begin{tabular}{|c|c|}
\hline $\begin{array}{l}\text { Bilangan } \\
\text { Gelombang }\left(\mathrm{cm}^{-1}\right)\end{array}$ & $\begin{array}{l}\text { Gugus Fungsi yang } \\
\text { Menyebabkan Absorbsi }\end{array}$ \\
\hline $3059,86-3025,14$ & Ulur C-H aromatik \\
\hline $2923,88-2849,63$ & Ulur C-H alkana \\
\hline $1943,15-1746,42$ & Tekuk C-H aromatik \\
\hline $1681,81-1650,95$ & $\begin{array}{l}\text { Ulur } C=C \text { alkena dalam } \\
\text { stirena }\end{array}$ \\
\hline $1600,81-1492,80$ & Ulur $\mathrm{C}=\mathrm{C}$ aromatik \\
\hline 1451,33 & Ulur C-H dalam stirena \\
\hline $1373,22-1027,02$ & $\begin{array}{l}\text { Tekuk luar bidang } \mathrm{C}-\mathrm{H} \\
\text { aromatik }\end{array}$ \\
\hline $964,34-906,48$ & $\begin{array}{l}\text { Tekuk C-H luar bidang } \\
\text { dalam stirena }\end{array}$ \\
\hline 841,87 dan 757,01 & Ulur C-O epoksida \\
\hline $702,04-540,03$ & $\begin{array}{l}\text { Tekuk luar bidang } \mathrm{C}-\mathrm{H} \\
\text { aromatik }\end{array}$ \\
\hline
\end{tabular}

Tabel 8. Hasil Analisis Gugus Fungsi Spektrum Infra Merah Sampel Perlakuan Radiasi Sinar UV Selama 40 Hari

\begin{tabular}{|c|c|}
\hline $\begin{array}{l}\text { Bilangan } \\
\text { Gelombang }\left(\mathrm{cm}^{-1}\right)\end{array}$ & $\begin{array}{l}\text { Gugus Fungsi yang } \\
\text { Menyebabkan Absorbsi }\end{array}$ \\
\hline $3101,32-3025,14$ & Ulur C-H aromatik \\
\hline $2923,88-2849,63$ & Ulur C-H alkana \\
\hline $1943,15-1746,42$ & Tekuk C-H aromatik \\
\hline 1666,38 & $\begin{array}{l}\text { Ulur } \mathrm{C}=\mathrm{C} \text { alkena dalam } \\
\text { stirena }\end{array}$ \\
\hline $1600,81-1492,80$ & Ulur $\mathrm{C}=\mathrm{C}$ aromatik \\
\hline 1451,33 & Ulur C-H dalam stirena \\
\hline $1373,22-1027,99$ & $\begin{array}{l}\text { Tekuk luar bidang C-H } \\
\text { aromatik }\end{array}$ \\
\hline $964,34-906,48$ & $\begin{array}{l}\text { Tekuk luar bidang C-H } \\
\text { dalam stirena }\end{array}$ \\
\hline 841,87 dan 757,97 & Ulur C-O epoksida \\
\hline $703,01-540,03$ & $\begin{array}{l}\text { Tekuk luar bidang C-H } \\
\text { aromatik }\end{array}$ \\
\hline
\end{tabular}

Pembentukkan stirena oksida ditunjukkan oleh spektrum gugus C-O dari epoksida yang terjadi di dekat bilangan gelombang $1250 \mathrm{~cm}^{-1}$ dengan karakter lemah. Pita lainnya muncul di daerah $950-810 \mathrm{~cm}^{-1}$ yang merupakan ulur cincin tak simetrik dengan karakter lemah, dan pita ketiga muncul di daerah 840-750 $\mathrm{cm}^{-1}$ yang berkarakter kuat. Berdasarkan Tabel 2, pada sampel kontrol sudah terbentuk stirena oksida yang ditunjukkan dengan adanya puncak epoksida pada bilangan gelombang 755,08 dengan karakter kuat dan 841,87 $\mathrm{cm}^{-1}$ dengan karakter lemah. Karena puncak spektrum C-O epoksida pada bilangan gelombang $841,87 \mathrm{~cm}^{-1}$ sangat lemah, sehingga yang diukur untuk mengetahui kandungan stirena oksida pada sampel adalah puncak pada bilangan gelombang 755,08 $\mathrm{cm}^{-1}$ yang berkarakter kuat. Pengukuran absorbansi gugus $\mathrm{C}-\mathrm{O}$ epoksida pada bilangan gelombang $755,08 \mathrm{~cm}^{-1}$ dengan menggunakan Persamaan 4 diperoleh 0,472; sedangkan ketebalan film dari sampel sebesar 0,165 mm. Jadi, hasil bagi dari absorbansi dengan ketebalan film sebesar 2,861. Nilai hasil bagi dari absorbansi dengan ketebalan film inilah yang merupakan konsentrasi relatif dari stirena oksida pada sampel kontrol. Stirena oksida dapat terjadi apabila sampel terpapar oleh radiasi sinar matahari maupun sinar ultra violet. Tetapi berdasarkan hasil penelitian ini, stirena oksida sudah terbentuk pada sampel kontrol, yaitu sampel yang tanpa diberi perlakuan oleh radiasi sinar matahari maupun sinar ultra violet. Hal ini dapat terjadi karena pengambilan atau perolehan sampel tidak langsung dari pabrik/produsen, tetapi dari toko ataupun pasar yang menjual 
styrofoam, sehingga dimungkinkan styrofoam tersebut sudah terpapar lama oleh sinar matahari.

Berdasarkan Tabel 3-7 bila dibandingkan dengan gugus fungsi spektra IR sampel kontrol pada Tabel 2, menunjukkan bahwa radiasi tidak mengakibatkan penambahan ataupun perubahan gugus fungsi pada sampel, hanya terjadi pergeseran frekuensi vibrasi dan peningkatan tinggi puncak spektrum. Hanya pada sampel dengan perlakuan radiasi sinar matahari selama 10 hari yang terjadi penambahan puncak baru yaitu muncul puncak pada bilangan gelombang $1245 \mathrm{~cm}^{-1}$. Puncak ini diprediksikan merupakan salah satu pita C-O epoksida. Munculnya puncak C-O di daerah 1250-an $\mathrm{cm}^{-1}$ dimungkinkan karena ketidakhomogenan dalam pembuatan sampel dimana pembuatan sampel tidak dilakukan secara serentak, sehingga dapat menyebabkan sampel yang masih dalam bentuk styrofoam sudah terjadi degradasi terlebih dahulu sebelum dibuat dalam bentuk film. Akibatnya, muncul pita C-O epoksida yang lain, meskipun puncak tersebut berkarakter lemah. Posisi pita IR dipengaruhi oleh beberapa faktor, yakni ikatan hidrogen dan konyugasi, dimana kedua hal ini menyebabkan penurunan frekuensi ulur (bilangan gelombang) vibrasi dan ketegangan atau ketegaran cincin yang menyebabkan peningkatan frekuensi vibrasi (Sutrisno, 2000). Pada spektra IR sampel kontrol maupun sampel dengan perlakuan radiasi, tidak menunjukkan adanya ikatan hidrogen maupun kemungkinan terjadinya konyugasi, maka terjadinya pergeseran frekuensi vibrasi dimungkinkan karena adanya ketegangan atau ketegaran cincin stirena ataupun stirena oksida yang terbentuk sehingga menyebabkan peningkatan frekuensi vibrasi.

Penentuan pengaruh radiasi sinar matahari maupun sinar ultra violet terhadap degradasi dapat dilihat dari terbentuknya stirena oksida yang ditunjukkan adanya spektrum gugus C-O dari epoksida. Semua jenis perlakuan radiasi pada sampel, menunjukkan terjadinya degradasi yang ditunjukkan adanya puncak epoksida. Gugus ini muncul pada bilangan gelombang $840-750 \mathrm{~cm}^{-1}$. Mekanisme reaksi yang terjadi pada sampel yang terdegradasi membentuk stirena oksida ditunjukkan pada Gambar 5.

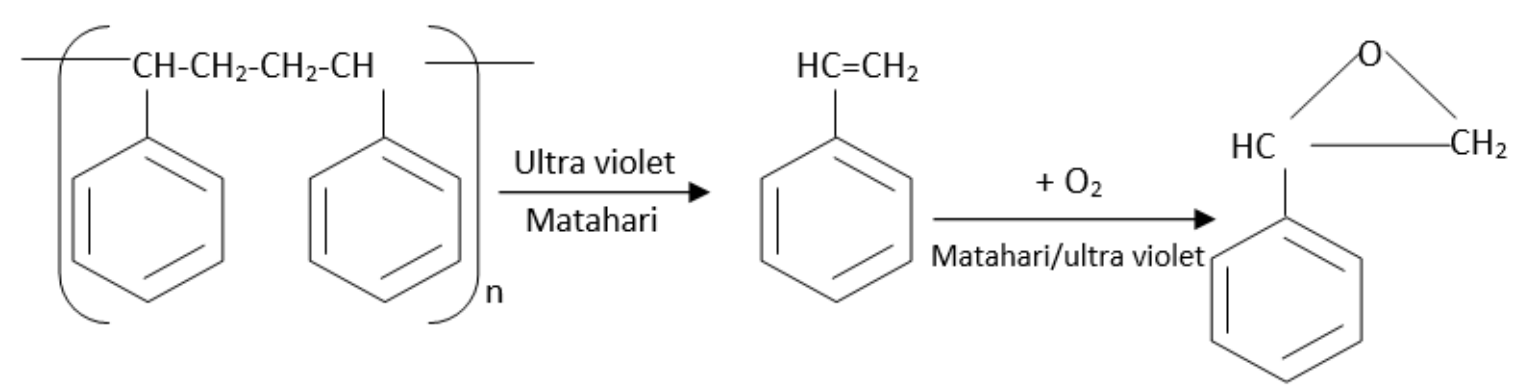

Gambar 5. Pembentukan Stirena Oksida pada Styrofoam

Pada spektra ketiga sampel ini, ada dua puncak yang menunjukkan terbentuknya stirena oksida, yaitu puncak pada bilangan gelombang sekitar 750-an dengan karakter kuat dan puncak pada bilangan gelombang sekitar 840-an dengan karakter lemah. Karena puncak pada bilangan gelombang sekitar 840-an sangat lemah, maka puncak yang diukur untuk menentukan pengaruh radiasi sinar matahari terhadap degradasi sampel adalah puncak pada bilangan gelombang 750-an yang berkarakter kuat. Data dari hasil pengukuran absorbansi gugus C-O epoksida, ketebalan film dari sampel, dan hasil bagi dari absorbansi dengan ketebalan film dengan menggunakan Persamaan 4 disajikan pada Tabel 9 dan Tabel 10.Berdasarkan hasil pengukuran di atas dapat dibuat grafik antara konsentrasi relatif stirena oksida dengan lama waktu perlakuan radiasi dengan sinar matahari maupun sinar ultra violet yang disajikan pada Gambar 6.

Tingkat pengaruh besarnya degradasi pada analisis spektroskopi infra merah ini dapat dilihat dari besarnya perbandingan nilai $\mathrm{A} / \mathrm{b}$ yang menunjukkan konsentrasi relatif stirena oksida pada masing-masing sampel. Makin besar nilai $\mathrm{A} / \mathrm{b}$ menunjukkan makin besar terjadinya degradasi pada sampel. Pada Gambar 4 menunjukkan bahwa semakin lama perlakuan radiasi baik sinar matahari maupun sinar ultra violet, makin besar terjadinya degradasi pada sampel. Dengan demikian, pengaruh radiasi sinar matahari maupun sinar ultra violet pada styrofoam 
Tabel 9. Hasil Pengukuran Absorbansi dan Ketebalan Sampel Perlakuan Radiasi dengan Sinar Matahari

\begin{tabular}{lllllll}
\hline No. & Waktu & Sampel & $\begin{array}{l}\text { Puncak Bilangan } \\
\text { Gelombang yang } \\
\text { Diukur }\left(\mathbf{c m}^{-1}\right)\end{array}$ & & b $(\mathbf{m m})$ & A/b \\
\hline 1. & Radiasi 10 Hari & 757,97 & 0,487 & 0,165 & 2,952 \\
\hline 2. & Radiasi 25 Hari & 757,01 & 0,454 & 0,145 & 3,131 \\
\hline 3. & Radiasi 40 Hari & 757,01 & 0,585 & 0,150 & 3,900 \\
\hline
\end{tabular}

Tabel 10. Hasil Pengukuran Absorbansi dan Ketebalan Sampel Perlakuan Radiasi dengan Sinar Ultra Violet

\begin{tabular}{|c|c|c|c|c|c|c|}
\hline No. & $\begin{array}{l}\text { Waktu } \\
\text { Perlakuan }\end{array}$ & Sampel & $\begin{array}{lr}\text { Puncak } & \text { Bilangan } \\
\text { Gelombang } & \text { yang } \\
\text { Diukur }\left(\mathrm{cm}^{-1}\right) & \\
\end{array}$ & A & B (mm) & $\mathbf{A} / \mathbf{b}$ \\
\hline 1. & Radiasi 10 hari & & 758,94 & 0,533 & 0,175 & 3,046 \\
\hline 2. & Radiasi 25 hari & & 757,01 & 0,458 & 0,145 & 3,159 \\
\hline 3. & Radiasi 40 hari & & 757,97 & 0,606 & 0,150 & 4,040 \\
\hline
\end{tabular}

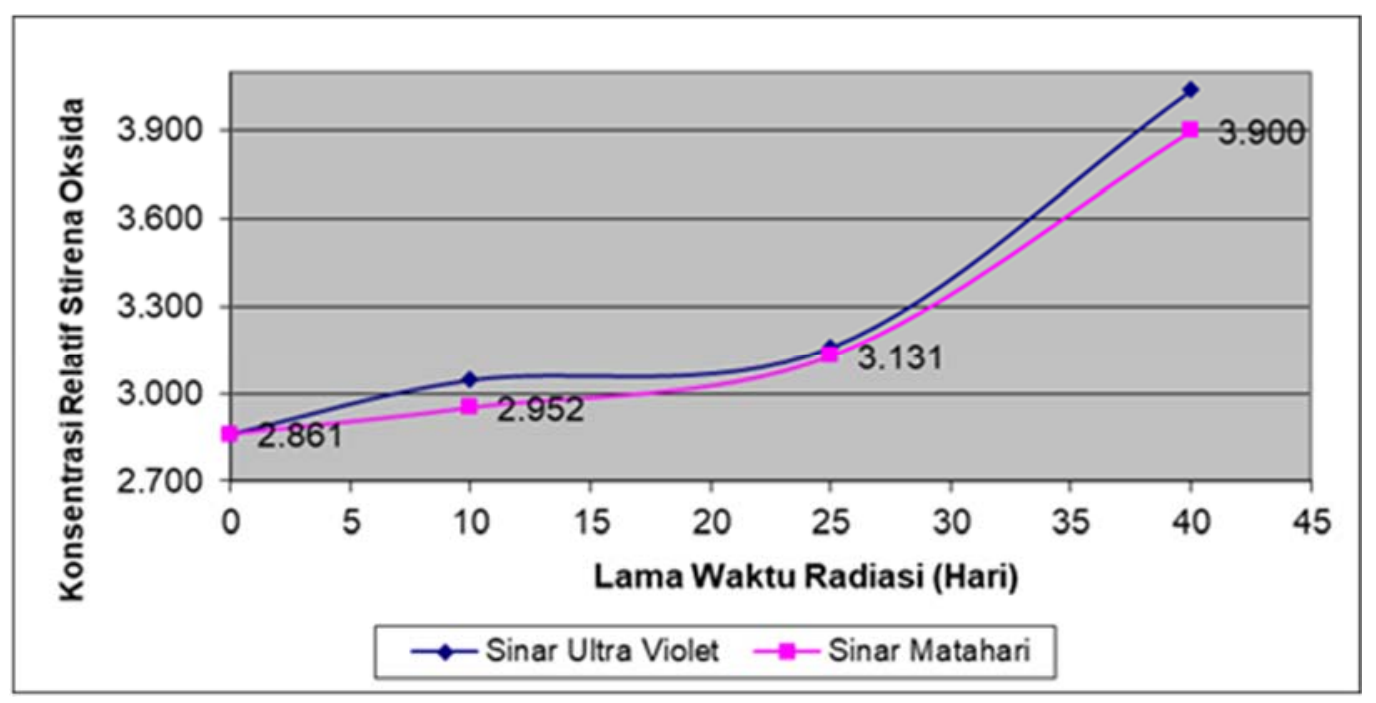

Gambar 6. Grafik Konsentrasi Relatif Stirena Oksida terhadap Lama Waktu Radiasi

kemasan makanan maupun minuman dapat menyebabkan degradasi styrofoam dan terbentuk stirena oksida. Oleh karena itu perlu perhatian khusus dalam penyimpanan styrofoam dengan cara menghindarkan dari paparan sinar matahari dan juga sinar UV. Jika kemasan makanan telah terdegradasi akan sangat mungkin terjadi migrasi partikel plastik hasil degradasi ke dalam makanan. Makanan atau minuman kontak dengan permukaan plastik dapat terjadi migrasi zat racun sehingga dapat menyebabkan mutasi gen dan merangsang sel kanker (Ikrawan, 2007). Stirena oksida adalah senyawa epoksida turunan dari stirena yang bersifat racun, mutagen, dan karsinogenik. Tetapi karena sifatnya akumulatif dalam tubuh, maka akibatnya baru akan terasa 1015 tahun kemudian.

\section{Pengamatan Fisik}

Pengamatan fisik yang dilakukan meliputi pengamatan penampakan permukaan dan warna. Hasil pengambilan gambar sampel kontrol dan sampel dengan perlakuan radiasi dapat dilihat pada Gambar 7.

Berdasarkan Gambar 7 (a) pada sampel kontrol, penampakan permukaannya rata dan warna dari sampel transparan. Pada sepuluh hari pertama untuk mengetahui ada dan tidaknya perubahan pada sampel, dapat dilihat dari penampakan permukaan dan warna sampel setelah diradiasi dengan sinar matahari. Berdasarkan Gambar 7 (b), dapat dilihat bahwa penampakan permukaan sampel setelah diradiasi dengan sinar matahari selama 10 hari muncul seperti butiran-butiran putih dan warna sampel berubah menjadi kuning kusam. Butiran-butiran 
ini mulai muncul pada hari ke-5 setelah sampel diradiasi dengan sinar matahari. Butiran putih ini dimungkinkan merupakan stirena dan atau stirena oksida yang terbentuk dari hasil degradasi styrofoam. Selain itu, sampel menjadi tampak keras permukaannya. Hal ini dapat terjadi karena pengaruh gabungan sinar matahari dan oksigen yang menyebabkan putusnya ikatan antar atom C (C-C) pada ikatan primer dalam strukturnya, sehingga sampel kelihatan ada retakan. Berubahnya warna sampel dari transparan menjadi kuning kusam dapat terjadi karena adanya hidrogen benzilik yang tidak stabil dalam styrofoam akibat pengaruh kondisi cuaca. Berdasarkan Gambar 7 (c) dan (d), semakin lama radiasi matahari yang dikenakan pada sampel, butiran-butiran putih yang muncul tampak semakin jelas dan warnanya tampak semakin kuning kusam. Selain itu, sampel juga tampak semakin banyak timbul retakan pada permukaannya.

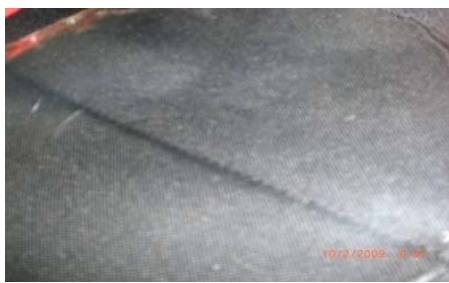

(a)

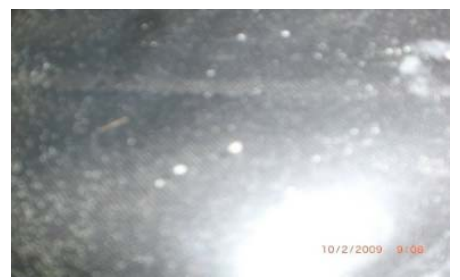

(d)

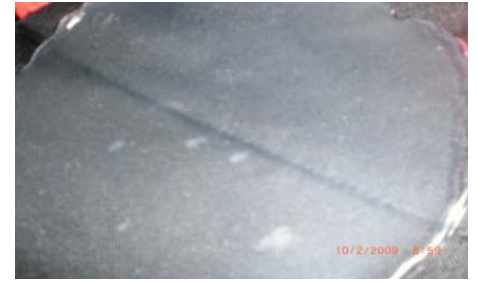

(b)

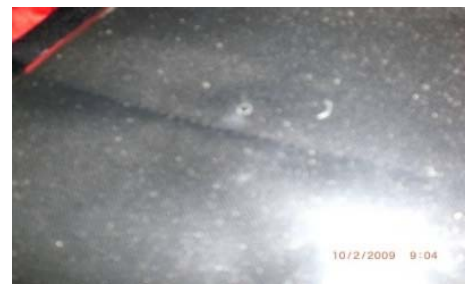

(e)

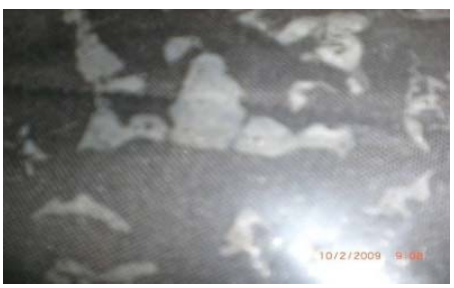

(g)

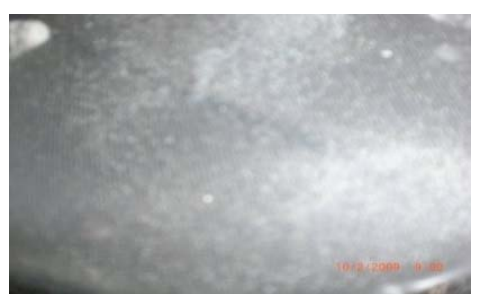

(c)

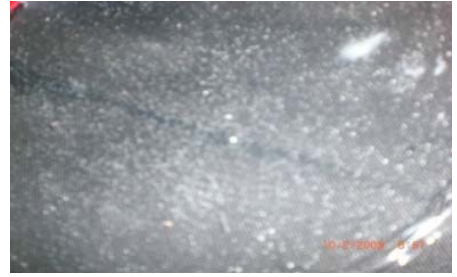

(f)

Gambar 7. Styrofoam tanpa perlakuan (a); Styrofoam setelah Diradiasi Sinar Matahari Selama 10 Hari (b); Matahari Selama 25 Hari (c); Matahari Selama 40 Hari (d); Sinar UV Selama 10 Hari (e); Sinar UV Selama 25 Hari (f); Sinar UV Selama 40 Hari (g)

Berdasarkan Gambar 7 (e), dapat dilihat bahwa penampakan permukaan sampel setelah diradiasi dengan sinar matahari selama 10 hari muncul seperti butiran-butiran putih. Butiranbutiran ini mulai muncul pada hari ke-3 setelah sampel diradiasi dengan sinar ultra violet dan tampak lebih banyak bila dibandingkan dengan sampel setelah diradiasi selama 10 hari dengan sinar matahari. Hal ini karena sinar UV memiliki energi radiasi lebih besar. Oleh karena itu, butiran-butiran yang muncul lebih banyak. Selain itu, sampel menjadi tampak keras permukaannya. Adanya bahan polimer yang transparan dapat menjadi kekuningan, disebabkan oleh adanya pelepasan atom hidrogen dari rantai sebagai radikal, akibat oksidasi yang menghasilkan ikatan rangkap dalam polimer dan akan membentuk struktur yang terkonyugasi (Cowd, 1991: 34). Berdasarkan Gambar 7 (f) dan (g), dapat dilihat bahwa semakin lama radiasi sinar ultra violet 
yang dikenakan pada sampel tampak semakin jelas dan sampel tampak semakin banyak retakan pada permukaannya. Hal ini menunjukkan semakin besar degradasi sampel yang terjadi.

\section{KESIMPULAN}

Berdasarkan hasil penelitian yang telah dilakukan dapat disimpulkan bahwa radiasi sinar matahari dan radiasi sinar ultraviolet dapat menyebabkan terjadinya degradasi pada plastik

\section{DAFTAR RUJUKAN}

Awang, R. M. 1999. Bahaya Bahan Kimia dalam pembungkus Plastik, (Online), (http://www.prn2.usm.my/mainsite/buletin /kosmik/12.html, diakses 14 Maret 2008 jam 17.29 WIB).

Billmeyer, F. W. 1984. Textbook of Polymer Science (3rd ed.). New York: John Willey and Sons.

Budiasih, E., dkk. 2003. Analisis Instrumentasi. Malang: IMSTEP- JICA FMIPA Universitas Negeri Malang.

Cavallo, D., Tranfo, G., Ursini, C.L., Fresegna, A.M., Ciervo, A., Maiello, R., Paci, E., Pigini, D., Gherardi, M., Gatto, M.P., Buresti, G., Iavicoli, S., 2018. Biomarkers of early genotoxicity and oxidative stress for occupational risk assessment of exposure to styrene in the fibreglass reinforced plastic industry. Toxicology Letters, Biomonitoring for chemical risk assessment and control 298, 53-59. https://doi.org/10.1016/j.toxlet.2018.06.00 6

Chen, Q., Zhang, H., Allgeier, A., Zhou, Q., Ouellet, J.D., Crawford, S.E., Luo, Y., Yang, Y., Shi, H., Hollert, H., 2019. Marine microplastics bound dioxin-like chemicals: Model explanation and risk assessment. Journal of Hazardous Materials 364, 8290.

https://doi.org/10.1016/j.jhazmat.2018.10. 032

Cherry, R. 1967. General Plastic Project and Procedures. USA: McKingt Company.

Clifford, dkk. 1972. Analisis Spektrum Senyawa Organik. Terjemahan oleh Kosasih Padmawinata dan Iwang Soediro. 1982. Bandung: ITB

Cowd, M. A. 1982. Kimia Polimer. Terjemahan oleh Harry Firman. 1991. Bandung: ITB styrofoam dengan dihasilkannya monomer stirena yang teroksidasi membentuk stirena oksida. Makin lama radiasi pada plastik styrofoam, makin meningkatkan terjadinya degradasi. Degradasi yang terjadi akibat radiasi sinar matahari dan sinar ultra violet dapat menyebabkan penurunan kekuatan tarik, peningkatan konsentrasi relatif stirena oksida, serta menyebabkan styrofoam menjadi berwarna kuning dan terjadi retakanretakan yang menandakan terjadi degradasi.

de Bomfim, A.S.C., Maciel, M.M.Á.D., Voorwald, H.J.C., Benini, K.C.C. de C., de Oliveira, D.M., Cioffi, M.O.H., 2019. Effect of different degradation types on properties of plastic waste obtained from espresso coffee capsules. Waste Management 83, 123-130. https://doi.org/10.1016/j.wasman.2018.11. 006

Demirkir, C., Colak, S., Aydin, I., 2013. Some technological properties of woodstyrofoam composite panels. Composites Part B: Engineering 55, 513-517. https://doi.org/10.1016/j.compositesb.2013 .07 .024

Editors, A., 2014. Toxicological and environmental effects of polystyrene. Access Science. https://doi.org/10.1036/10978542.BR0807141

FLEIG, I., THIESS, A.M., 1978. Mutagenicity study of workers employed in the styrene and polystyrene processing and manufacturing industry. Scandinavian Journal of Work, Environment \& Health 4, 254-258.

Huff, J., Infante, P.F., 2011. Styrene exposure and risk of cancer. Mutagenesis 26, 583-584. https://doi.org/10.1093/mutage/ger033

Ikrawan, Y. 2008. "Styrofoam”, Amankah untuk Makanan?, (Online), (http://www.pikiranrakyat.com, diakses 14 Maret 2008 jam 17.08 WIB).

Martínez-Romo, A., González-Mota, R., SotoBernal, J.J., Rosales-Candelas, I., 2015. Investigating the Degradability of HDPE, LDPE, PE-BIO, and PE-OXO Films under UV-B Radiation [WWW Document]. Journal of Spectroscopy. https://doi.org/10.1155/2015/586514

Mobrianto, D. N. 2003. Pengaruh Konsentrasi Pati dan Sinar Ultra Violet terhadap Sifat 
Fisik Poliblend High Density Polyethylene (HDPE)-Pati. Skripsi tidak diterbitkan. Malang: Universitas Negeri Malang.

Mujiarto, I. 2 Desember, 2005. Sifat dan Karakteristik Material Plastik dan Bahan Aditif. Traksi. Vol. 3. No. 65

Nurhayati. 2007. Sintesis Poliblend PolistyrenePati Tapioka, (Online), (http://www.library.itb.ac.id/download/nur hayati.pdf, diakses 10 Maret 2009 jam 10.05 WIB).

Radiman, C. L. 2004. Kimia Polimer. Bandung: ITB

Sastrohamidjojo, H. 1990. Spektroskopi Infra Merah. Yogyakarta: Liberti.

Shrivastava, A., 2018. 3 - Plastic Properties and Testing, in: Shrivastava, A. (Ed.), Introduction to Plastics Engineering, Plastics Design Library. William Andrew Publishing, pp. 49-110. https://doi.org/10.1016/B978-0-32339500-7.00003-4

Stevens, M. P. 1989. Kimia Polimer. Terjemahan oleh Iis Sopyan. 2001. Jakarta: PT. Pertja.

Sudjadi. 1985. Penentuan Struktur Senyawa Organik. Jakarta: Balai Aksara.

Zamroni, A. 2002. Studi Pengaruh Radiasi Sinar Matahari dan Sinar Ultra Violet terhadap Plastik Polistirena. Skripsi tidak diterbitkan. Malang: Universitas Negeri Malang. 